\title{
Lionel Wordsworth Hinxman, B.A.
}

LIONEL WORDSWORTH HINXMAN was born on March 2I, I855, at Dunmore in Stirlingshire, where his father was private chaplain to Lord Dunmore. On the return of the family to England in I 862 he was sent first to Marlborough and later to Cheltenham, and then entered Christ's College, Cambridge. He graduated there in 1877 . In 1883 he was appointed Temporary Assistant Geologist on the Geological Survey of Scotland, became Geologist in I90I, and District Geologist in 1905, and retired in I919. His last years were spent quietly at Ringwood in the New Forest area, where he died on April 29, 1936.

$H$ is main contributions to science are to be found in the memoirs and maps issued by the Geological Survey. He prepared detailed sixinch maps of large areas in different parts of the Scottish Highlands, and some of the districts he investigated and described have become classic. The work he accomplished has been rather overlooked, but it should not be forgotten that he constructed the detailed geological maps of the Cape Wrath country, of Quinag and Beinn Garbh in Assynt, of Cùl Mor and the Knockan area on the borders of Sutherland and Ross, and of the wild mountainous region at the head of Loch Torridon. Among the more important memoirs to which he contributed may be cited: "The Geological Structure of the North-West Highlands of Scotland" (1907); "Lower Strathspey" (I9O2); "Edinburgh District" (I9IO); "Glasgow District" (I9I I and I925); "Ben Wyvis," etc. (I9I2); "Fannich Mountains," etc. (I9I3); "Upper Strathspey," etc. (I9I3); "Central Rossshire" (1913); "Beauly and Inverness" (1914); "Mid-Strathspey and Strathdearn" (I9I 5).

A pronounced stammer made him reluctant to deliver addresses or to take part in debates. He contributed, however, from time to time to the Scottish Geographical Magazine ("Studies of Scottish Rivers," etc.), to the Journal of the Scottish Mountaineering Club ("The Geology of the Scottish Mountains," etc.), to the Transactions of the Edinburgh Geological Society, and to other scientific publications. In I894, in collaboration with Dr W. Eagle Clarke, he contributed to the Transactions of the Royal Physical Society of Edinburgh an important paper on "The Vertebrate Fauna of West Ross-shire." He was a recognised authority on the bird life of Scotland, and in his early days an enthusiastic mountaineer. 
A man of an unassuming and retiring nature, he had none the less many friends in all walks of life, drawn to him by his innate courtesy and kindliness, his sincerity of purpose, and his loyalty to the traditions he inherited. He had many interests, but was never so happy as when engaged in deciphering the secrets of his beloved mountains.

He was elected a Fellow of the Society in 1902.

M. M. 